\title{
A Survey on the Transient Stability of Power Systems with Converter Connected Distributed Generation
}

\author{
Muhamad Reza ${ }^{1,2}$ \\ ${ }^{1}$ Electrical Power System Laboratory, Delft University of Technology, Delft, the Netherlands \\ (The author's affiliation when the work was performed) \\ ${ }^{2}$ ABB Corporate Research, Västerås, Sweden
}

\begin{abstract}
In the classical (vertical) power systems the synchronous operation of every interconnected syndronous madhine(with its inherently rotating masses - inertia) is the main requirement for stable operation. As many of thedistributed generation technologies are connected to the distribution network via power electronic interfaces, and do not contain inetia, thepower system may show different transient stability phenomena. In this paper, the transient stability ofpowersystems with (inetia less) converter connected distributed generation is explored via the Equal Area Criterion method and compared with that ofa traditional (vertical) power system. With the existence of a strong external system, it is fund that asystem with ahigher level of penetration of DG exhibits better stability, as measured by improved critical cleaing times oftheremaining syndronous generator(s).
\end{abstract}

Keywords: converter connected distributed generation, power systems transient stability

\begin{abstract}
ABSTRAK
Pada sistem tenaga listrik klasik, sinkronisasi di dalam pengoperasian seluruh generator serempak(yang masing memiliki kelembaman/momen inersia) yang terhubung pada sistem adalah persyaratan yang utama untukkestabilan operasi system tersebut. Dengan banyaknya pembangkit listrik tersebar yang terhubung pada jaringan distribusi listrikmelalui perangkat elektronika daya, yang tidak dilengkapi dengan kelembaman/ momen inersia, akan menghasilkan fenomena kestabilan yang berbeda. Di dalam makalah ini, akibat penerapan pembangkit listrik tersebar yang terkoneksi melalu perangkat elektronika data terhadap kestabilan transien dari sebuah sistem tenaga listrikakan diamati dengan menggunakan metoda "Equal Area Criterion". Hasil pengamatan kemudian dibandingkan dengan kestabilan transien sebuah sistem tenaga listrikkasik Di dalam makalah ini ditemukan bahwa ketika sebuah sistem tenaga listrik masih terkoneksi dengan jaringan listrikeksternal yang rigid, maka penerapan pembangkit listrik tersebar akan meningkatkan kestabilan operasi sistem, yang ditunjukkan dengan peningkatan "critical clearing times" dari generator serempak yang terhubung ke sistem tersebut.
\end{abstract}

Kata kunci: pembangkit listrik tersebar terhubung dengan perangkat elektronika daya, kestabilan transien sistem tenaga listrik

\section{INTRO DUCTION}

Driven by the increasingenvironmental concemsit is expected that many new generation technologies, including renewable generation, will be connectedto the electrical power system as distributedgeneration (DG).

\section{Interfacing DG with Power Electronics}

There are a lot of different DGtechnologies, basedon distinct energy sources, such as co-generation, wind turbines, small hydro and fossil-fuelled generators, photovoltaic systems, fuel cells andmicro-generation [1]. These DG units, especially the ones whose prime movers are based on renewable energy sources with intermittent characteristics (like windandsolar), are mostly connected to the distribution net work via power electronic interfaces, which are primarily used to maximize the energy yield [2].

Note: Discussion is expected before June, $1^{\text {st }} 2007$. The proper discussion will be published in Electrical Engineering Journal volume 7, number 2, September 2007.

\section{Inertia of Synchronous Generator}

The transient stability is definedasthe property of a power system to return to a stable operatingpoint after the occurrence of a disturbance [3, 4]. Traditionally, the transient stability problem is to maintain the synchronous operation of the synchronous generators in the system, i.e. to keep the operation speedof the rotors of all synchronous generators constant, which will result in constant angular position between two machines $[3,5]$.

The fundamental equation that governsthe rotational dynamics of the synchronous generator is represented by means of the swing equation $[3,5]$ :

$$
\frac{2 H}{\omega_{s}} \frac{d^{2} \delta}{d t^{2}}=P_{a}=P_{m}-P_{e}
$$$$
\text { [pu] }
$$

Where, $\mathrm{H}$ is the stored kinetic energy at synchronous speed per MVAbase, $\delta$ is the angular displacement of the rotor in rad, Pm is the shaft power input less 
rotational losses in pu., $\mathrm{Pe}$ is the electrical power crossing the air gap in pu., $\mathrm{Pa}$ is the accelerating power in pu., $\omega$ s synchronousspeedin electrical units in $\mathrm{rad} / \mathrm{s}$ and $\mathrm{t}$ is the time in $\mathrm{s}$.

The more rotational massthe synchronous generator has, the less the generator rotor will respondto an accelerating or decelerating tendency due to a disturbance.

\section{CO NVERTER C O NNEC TED DIS TRIBUTED GENERATIO N}

When DG is connected to power systems via apower electronic interface, no inertia is addedto the system because:

- The DG itself generates DC power (i.e. $f=0$ ), e.g photovoltaic and fuel cells (figure 1).

- The inertia of the DG whoseprimemover involves rotating masses is 'hidden' behindthepower electronic interface by decouplingthemechanical rotor speed of the DGwith the electrical frequency of the grid (figure 2).

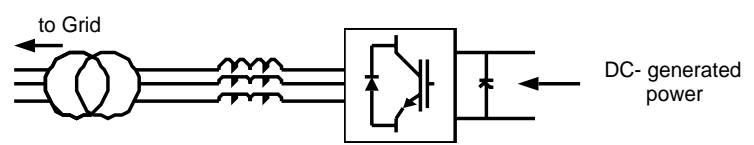

Figure 1. Connecting DG with DC output power to the power system

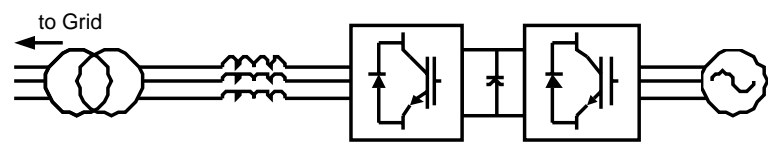

Figure 2. Connecting DG with rotatingmachines to the power system via a power electronic interface

Thus, in the above-mentionedsituations, the DGwill not change the acceleration or deceleration of the synchronous generators in the grid, in case of a mismatch between generation andloadin the system [4].

\section{Transient Analysis Simulation}

In this study, the transient behavior of a power system with converter connected DG is investigated by means of simple test system (shoun in figure3) that consists of 5 buses:

- Bus 2 is an infinite bus (to represent an intercomnection with a large external system),

- A plant containing similar and coherent CGs (every CG implemented in thisbusisidentical and the rotors of all the machine rotate and swing coherently just like all the rotorsaremechanically coupled) is connected to bus 1 ,

- The load that is representedas constant impedance during the transient analysisis connectedto bus5. DG supplying only active power isconnectedto bus 5 and modelled as negative load.

Figure 4 shows the reactance diagram of the pre-fault test system. Table 1 liststhe values of theparameters used in the test system.

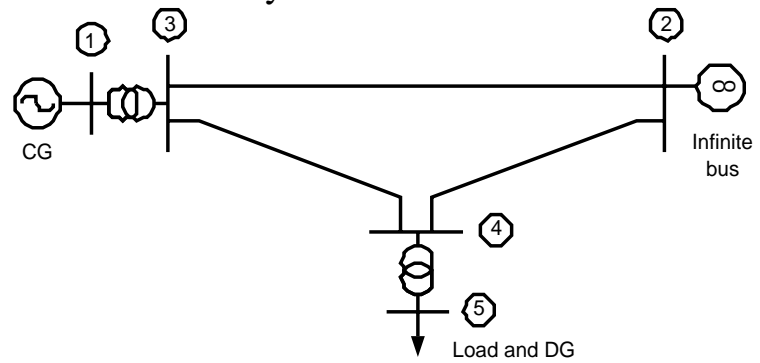

Figure 3. One-line diagram of the test system

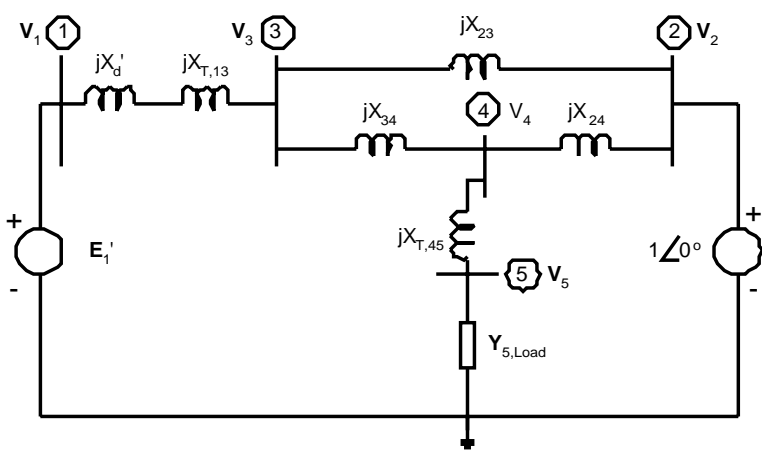

Figure 4. Reactance diagram of the test system in the pre-fault (steady- state) situation

Table 1. Values of the parameters used in the simut lation

\begin{tabular}{cccccc}
\hline Parameter: & Value & Parameter & Value & Parameters & Value \\
\hline MVA $_{\text {syst. }}$ & $100 \mathrm{MVA}$ & $\mathrm{X}_{\mathrm{T}, 13}$ & $0.005 \mathrm{pu}$ & $|\mathrm{V}|_{\text {inf }}$ & $1.0 \mathrm{pu}$ \\
$\mathrm{V}_{\text {transmission }}$ & $220 \mathrm{kV}$ & $\mathrm{X}_{\mathrm{T}, 45}$ & $0.005 \mathrm{pu}$ & $\delta_{\mathrm{nf}}$ & $0^{\circ}$ \\
$\mathrm{V}_{\mathrm{CG}}$ & $20 \mathrm{kV}$ & $\mathrm{X}_{23}$ & $0.02 \mathrm{pu}$ & $\mathrm{V}_{\text {Load }}$ & $20 \mathrm{kV}$ \\
& & $\mathrm{X}_{24}$ & $0.02 \mathrm{pu}$ & $\mathrm{P}_{\text {Load }}$ & $2000 \mathrm{MW}$ \\
& & $\mathrm{X}_{34}$ & $0.01 \mathrm{pu}$ & $\mathrm{Q}_{\text {Load }}$ & $100 \mathrm{MVAR}$ \\
\hline
\end{tabular}

Ten cases are developed by gradually increasing the amount of converter connected DG. The DG is connected at the same bus as the load (bus 5) and supplies active power only. Therefore, the DGis regarded as negative load in the loadbus. In the first case (case 1), no DG is connectedin theloadbus, and the load is completely supplied by 10 identical CG units in bus 1 . By increasingthe DGpenetration level in steps of $10 \%$ of the active load, oneCGunit is shutdown in every case, which results in an altered value of $X_{d}$ ' too (since the CGs are assumedto bein parallel), so that in the last case only one CGremains in the system. The details of the 10 casesdeveloped are listed in Table 2. 
Table 2. Values of the parameters used in the 10 simulation cases

\begin{tabular}{|c|c|c|c|c|c|}
\hline $\begin{array}{l}\text { Case } \\
\text { [nr.] }\end{array}$ & $\begin{array}{c}\text { CG } \\
\text { [\# units] }\end{array}$ & $\begin{array}{c}\text { Total CG- } \\
\text { Real-Power } \\
\text { Output }\left(P_{\mathrm{m}}\right) \\
{[\mathrm{MW}]}\end{array}$ & $\begin{array}{c}\text { Total DG- } \\
\text { Real-Power- } \\
\text { Output } \\
\left(\mathbf{P}_{\mathrm{DG}}\right)[\mathrm{MW}]\end{array}$ & 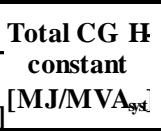 & $\begin{array}{c}\text { CG } \mathrm{X}_{\mathrm{d}} \text { ' } \\
{[\mathrm{pu}]}\end{array}$ \\
\hline 1 & 10 & 2000 & 0 & 100.0 & $\mathrm{j} 0.0100$ \\
\hline 2 & 9 & 1800 & 200 & 90.0 & $\mathrm{j} 0.0111$ \\
\hline 3 & 8 & 1600 & 400 & 80.0 & $\mathrm{j} 0.0125$ \\
\hline 4 & 7 & 1400 & 600 & 70.0 & j0.0143 \\
\hline 5 & 6 & 1200 & 800 & 60.0 & j 0.0167 \\
\hline 6 & 5 & 1000 & 1000 & 50.0 & $\mathrm{j} 0.0200$ \\
\hline 7 & 4 & 800 & 1200 & 40.0 & $\mathrm{j} 0.0250$ \\
\hline 8 & 3 & 600 & 1400 & 30.0 & j 0.0333 \\
\hline 9 & 2 & 400 & 1600 & 20.0 & j0.0500 \\
\hline 10 & 1 & 200 & 1800 & 10.0 & ¡ 0.1000 \\
\hline
\end{tabular}

The constant load model $\mathbf{Y}_{5, \text { Load }}$ (figure 4) iscalar lated as:

$$
\mathbf{Y}_{5, \text { Load }}=\frac{\left(P_{\text {Load }}-P_{D G}\right)-j Q_{\text {Load }}}{\left|\mathbf{V}_{5}\right|^{2}} \quad[\mathrm{pu}]
$$

The impact of converter connected DGduringthe fault (transient situation) ismodelledin such that the DGs disconnect during the fault, so that (duringthe fault) no negative load is implemented $\left(P_{D G}\right.$ in equation (2) equals to zero). The values of $\mathbf{V}_{5}$ in equation (2) are obtained by running a load flow program with PSS/E 25.4 on the pre-fault condition of every case. The transient stability of the test system is investigated by applying a temporary three-phase fault to a transmission line in themiddle of line 3-4 (See figure 3).

Since the test system can be regarded as a single machine infinite bus (SMIB) system (sinceall the synchronous machines in bus 1 are coherently operated) the Equal Area Criterion [6] is usedto investigate the transient stability phenomena of each case in every scenario. To assessthe transient stability performance, one indicator is used, namely the critical clearing time $\left(t_{c r}\right)$, which is defined as the maximal time needed to clear the fault present in the system without causing instability.

By deriving the admittance matrix $\mathbf{Y}_{\text {bus }}$ (5x5), along with the corresponding reduced admittance matrix $\mathbf{Y}_{\text {bus }}^{\prime}$ (2x2), that explicitly relatesbus 1 andbus2, the values of $P_{e}$ (thus $P_{c}, P_{\max }$, and $\delta$ ), of every case and every (sub-) scenarios (in both pre/post fault and during fault conditions) for equations(3)-(6) $[4,6,7]$, are calculated. Subsequently, the critical angles $\left(\delta_{r}\right)$ are calculated using the equal area criterion (equation (7)) $[3,5]$. Finally, the corresponding critical dearing times $\left(t_{c r}\right)$ - the time needed to achieve the critical angles $\left(\delta_{c r}\right)$ - are comput editeratively using equations (8)-(10) [5].

$$
\begin{aligned}
& P_{e}=P_{c}+P_{\max } \sin (\delta-\gamma) \\
& P_{\max }=\left|\mathbf{E}_{1}^{\prime}\right|\left|\mathbf{E}_{2}^{\prime}\right|\left|\mathbf{Y}_{12}^{\prime}\right| \\
& P_{c}=\left|\mathbf{E}_{1}^{\prime}\right|^{2} G_{11}^{\prime} \\
& \gamma=\theta_{12}^{\prime}-\frac{\pi}{2} \\
& \int_{\delta_{0}}^{\delta_{r r}} P_{m}-P_{e, \text { durim-fault }}(\delta)=\int_{\delta_{c r}}^{\delta_{\max }} P_{e, p r e / \text { post }- \text { faut }}(\delta)-P_{m} \\
& \delta_{n}=\delta_{n-1}+\Delta \delta_{n} \\
& \Delta \delta_{n}=\Delta \delta_{n-1}+\left(\frac{\pi f}{H}\right)(\Delta t)^{2}\left(P_{a, n-1}\right) \\
& P_{a, n}=P_{m}-P_{e}\left(\delta_{n}\right)
\end{aligned}
$$

Where $\mathbf{E}_{1}^{\prime}$ is the transient internal voltage of OGin $\mathrm{pu}, \mathbf{E}_{2}^{\prime}$ is the transient voltage of theinfinitebus, i.e. 1.0 in pu., $P_{m}$ is the shaft power input less rotational losses in pu., $\mathbf{Y}_{12}^{\prime}, \theta_{12}^{\prime}, G_{11}^{\prime}$ are respectively the admittance (in pu.), angle ( in rad), andsusceptance( in pu.) elements of reduced $\mathbf{Y}_{\text {bus }}^{\prime}(2 \times 2), P_{\text {edduning-faulb }}$ $P_{e, p r e / p o s t ~ f a u l t}$ are the electrical power crossingtheair gap during fault and pre-/post-fault (both in pu), $\delta_{0}, \delta_{c r}$, $\delta_{\max }$ are respectively the initial-, critical-, and maximum- rotor angles (all in rad)(SeeFigire6), $\Delta \delta_{n}, \delta_{n}$ are respectively the change in angle andthe angle in the $n$-interval iteration ( both in rad), $f$ is system frequency in Hz., $\Delta t$ is the iteration time interval in s, and $P_{a, n}$ is the acceleratingpower at the middle of the iteration interval in pu.

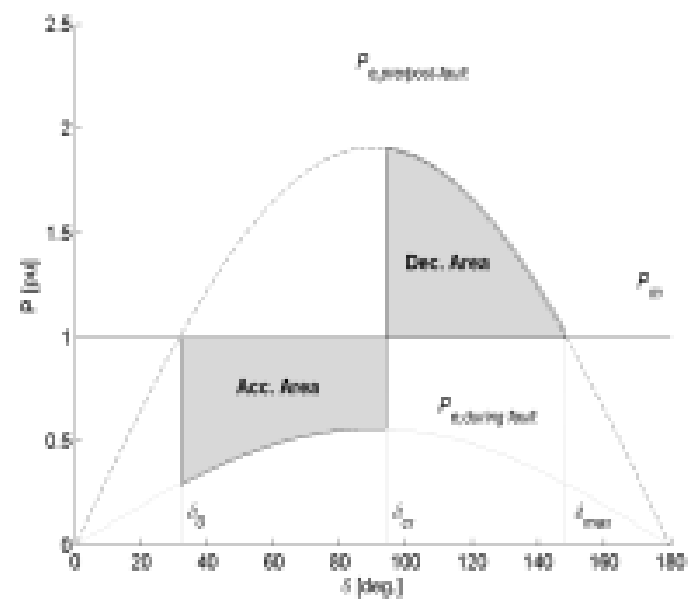

Figure 6. Plot of power-angle curvestypically found in every simulation case, showingthe initial $(\delta 0)$, critical ( $\delta c r)$, and maximum ( $\delta$ max) angles. The accelerating (Acc.) area and decelerating (Dec.) area are equal. 


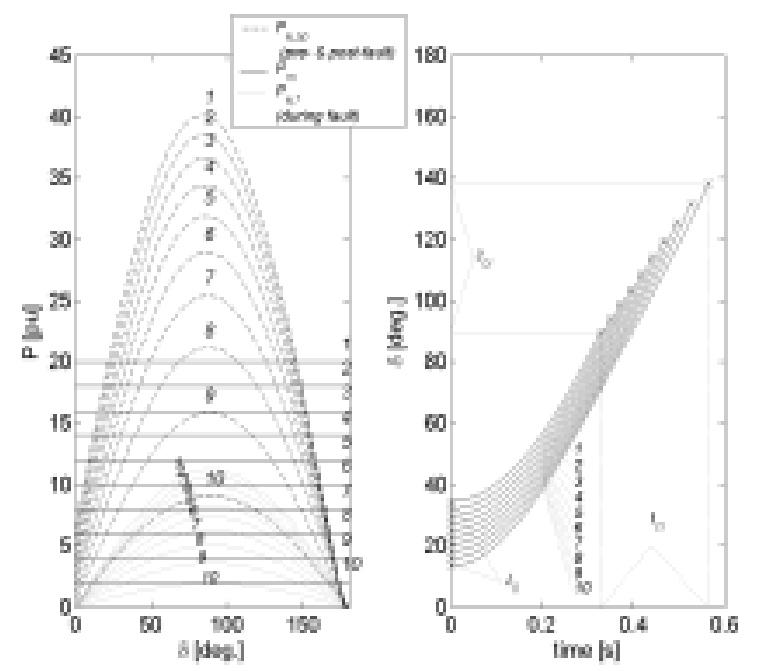

Figure 7. The results when Fault \#1 is simulatedon either Scenarios I or II (10 cases). Left graph: Plots of the power-angle curves. Right graph: Swing curves plotteduntil the point where the critical angles $(\delta c r)$ are reached on the critical times (tcr)

\section{RESULTS}

Figure 7 shows the results of Scenario I (10 cases). It is shown in the left graph of figure 7, that when the number of CG units decreases, the plots of $P_{m}$, $P_{e, \text { preppost-fault, }}$ and $P_{e}$,during fault, andthe $\delta_{\delta}$ decrease, whereas the $\delta_{\max }$ increases. Application of the equal area criterion (See Equation (8) andFigre6) results in rising $\delta_{c r}$-values when the number of CG units connected to the system falls. Although $H$ is decreasing (when the number of CGunitsdecreases, see Table 2) - so that aparticular rotor angle wouldbe reached faster if all the other parameters in equations (9) are kept the same - the time neededto reach a particular $\delta_{c r}$, i.e. $t_{c r}$, is longer (as can beseen in the right graph of figure 7). This iscausedby the fact that two opposite effects play a rolewhen thenumber of CG units is reduced: less $H$ versus a changing net work topology (altered value of $X_{d}$, sincethe OCs are assumed to be in parallel). This last effect is the strongest (in this case) andresilts in lower $P_{m} P_{\text {eprepost }}$ fault, $P_{e}$, during fault curves and $\delta_{0}$-values. Figire 7: (left graph) shows these situations, whereashigher $\delta_{\max }$ and $\delta_{c r}$-values are obtainedwhich leads to longer critical clearing times and better stability.

Table 3 shows the critical angles $\left(\delta_{c r}\right)$ and critical clearing times $\left(t_{c r}\right)$ that resultedfrom the simulation of all the cases.
Table 3. Simulation results

\begin{tabular}{ccccc}
\hline Case [nr.] & $\boldsymbol{\delta}_{\mathbf{0}}$ (deg.) & $\boldsymbol{\delta}_{\max }(\mathbf{d e g})$. & $\boldsymbol{\delta}_{\mathbf{c r}}(\mathbf{d e g})$. & $\mathbf{t}_{\mathbf{c r}}(\mathbf{s})$ \\
\hline 1 & 34.59 & 145.41 & 90.06 & 0.328 \\
2 & 32.18 & 147.82 & 94.44 & 0.349 \\
3 & 29.82 & 150.18 & 99.04 & 0.371 \\
4 & 27.51 & 152.49 & 103.86 & 0.394 \\
5 & 25.22 & 154.78 & 108.92 & 0.417 \\
6 & 22.94 & 157.06 & 114.22 & 0.441 \\
7 & 20.66 & 159.34 & 119.79 & 0.466 \\
8 & 18.35 & 161.65 & 125.66 & 0.495 \\
9 & 15.98 & 164.02 & 131.86 & 0.527 \\
10 & 13.52 & 166.49 & 138.46 & 0.565 \\
\hline
\end{tabular}

\section{CONCLUSIONS}

In this study, a simple 5-bussystemis used The equal area criterion is used to assess the systemtransient performance, and the critical fault clearing time, which is defined as the maximal timeneededto clear the fault applied in the system without causing instability, is used as the system stability indicator.

The results in this paper showwith the existence of a strong external system, abetter stability isobtained, as measured by longer critical fault dearingtimes of the remaining synchronous generator(s).

\section{Acknowledgement}

This research has been performed within the framework of the research program 'intelligent power systems' (http://www.intelligentpowersystemsnl) that is supported financially by Senter. Senter isan agency of the Dutch Ministry of Economic Affairs. The author would like to thank, Dr. P.H. Schavemaker and Prof. W.L. Kling from the Transmission System Operator, TenneT bv, ArnhemtheNetherlands and Prof. L. van der Sluis and Dr. M. Gibescufrom the Electrical Power System Research Group, Delft University of Technology, the Netherland, for the discussions and suggestions duringthe preparation of this paper.

\section{REFERENC ES}

[1] N. Jenkins. "Impact of DispersedCeneration on Power Systems”. ELECTRA, No. 199, 1999.

[2] J. H. R. Enslin. "Interconnection of Distributed Power to the Distribution Network". In Proceedings of IEEE Young Researcher Symposium, Delft, the Netherlands, Delft, the Netherlands, 18-19 March 2003.

[3] P. Kundur. Power System Stability and Control. McGraw-Hill Inc., 1994. 
[4] J. G. Slootweg. Wind power: Modelling and impact on power systemsdynamics(PhDThesis). Electrical Power Systems Laboratory, Delft University of Technology.

[5] J. J. Grainger and W. D. Stevenson. Power System Analysis. McGraw-Hill Inc., 1994. 